\title{
METHODOLOGICAL CHALLENGES FOR INTERNATIONAL EMPIRICAL STUDIES ON POPULIST POLITICAL COMMUNICATION*
}

\author{
WYZWANIA METODOLOGICZNE DLA \\ MIĘDZYNARODOWYCH BADAŃ EMPIRYCZNYCH \\ NAD POPULISTYCZNYM KOMUNIKOWANIEM POLITYCZNYM
}

Agnieszka Stępińska**, Dorota Piontek***, Jakub Jakubowski****

\section{- ABSTRACT}

The objective of this paper is to analyze two research tools applied in the social sciences for quantitative and qualitative studies respectively, namely codebook, or coding scheme, and individual in-depth interview - in terms of their applicability for studies of populist political communication. To this end, three codebooks serving as the tools of media content analysis in the above-mentioned international studies conducted in Europe in 2012-2017 are critically reviewed, and the structure of a questionnaire for in-depth interviews planned within the COST Action IS1308 Populist Political Communication in Europe: Comprehending the Challenge of Mediated Political Populism for Democratic Politics is analyzed.

\begin{abstract}
ABSTRAKT
Celem niniejszego artykułu jest przeanalizowane dwóch narzędzi badawczych wykorzystywanych w naukach społecznych w odpowiednio - ilościowych lub jakościowych - badaniach: książki kodowej, zwanej też kluczem kategoryzacyjnym oraz pogłębionego wywiadu indywidualnego pod kątem ich przydatności do badań nad populistycznym komunikowaniem politycznym. Służyć temu będzie krytyczny przegląd książek kodowych stanowiących narzędzia do analizy zawartości mediów w trzech badaniach międzynarodowych prowadzonych w Europie w latach 2012-2017, a także analiza struktury kwestionariusza wywiadu pogłębionego zaplanowanego $\mathrm{w}$ ramach projektu realizowanego $\mathrm{w}$ ramach Akcji COST IS 1308 Populist Communication in
\end{abstract}

* The paper is funded by the National Programme of Development for Humanities, Ministry of Science and Higher Education, grant no. 0131/NPRH4/H2b/83/2016.

** Adam Mickiewicz University in Poznań, Faculty of Political Science and Journalism.

$* * *$ Adam Mickiewicz University in Poznań, Faculty of Political Science and Journalism.

$* * \star *$ Adam Mickiewicz University in Poznań, Faculty of Political Science and Journalism. 
Keywords: populism; political communication; quantitative methods; qualitative methods; codebook; individual in-depth interview
Europe: Comprehending the Challenge of Mediated Political Populism for Democratic Politics.

Słowa kluczowe: populizm; komunikowanie polityczne; metody ilościowe; metody jakościowe; książka kodowa; pogłębiony wywiad indywidualny

\section{INTRODUCTION}

The recent electoral successes of populist parties in Europe and elsewhere have been accompanied by an increased interest in populism and the reasons for the support populist parties and political leaders have gained. This interest has resulted in a series of studies conducted in order to determine and understand the characteristics of political actors and their views on the one hand, and the voters who support them on the other (cf. Aalberg et al., 2017). Nevertheless, in order to understand their success, it is necessary to account for the process of communication between political actors, the media (journalists) and society (voters).

Adopting the perspective of political communication, populism may be defined as "a set of features or elements of communicative messages that have their roots in - or resonate with - the goals, motives, and attitudes of political actors, the media, or citizens" (Reinemann et al., 2017). In this approach, populism is "a communication style" or "a communication frame that appeals to and identifies with the people and pretends to speak in their name" (Jagers, Walgrave, 2007). According to Jagers and Walgrave (2007), it is "a master frame, a way to wrap up all kinds of issues" Rooduijn (2014) has a similar attitude to populism, which in his opinion is "a characteristic of a specific message rather than a characteristic of an actor sending that message".

Adopting this research perspective in populism studies makes it possible to focus not only on ideology (expressed through the statements and activities of political agents) but also on the role the media play in disseminating this ideology, as well as the views, stances and expectations of voters (Reinemann et al., 2017). Additionally, it allows an extensive range of entities to be studied without defining them in advance as populist or not. This attitude assumes that a populist 
style may to a greater or smaller extent be employed by all political actors, journalists and citizens alike (Akkerman, Mudde, Zaslove, 2014; Rooduijn, 2014).

In order to characterize a populist style it is necessary to refer to other perspectives, in particular those that describe populism as "a thin ideology" (Freeden, 1996; Muddle, 2004), "a discourse practice" (Laclau, 2005), or as a "mental map through which individuals analyse and comprehend political reality" (Mudde, Rovira Kaltwasser, 2013). The starting point is the identification of properties of this ideology and basic populist categories.

Populism assumes a dichotomous division into a positively valued category "us" - the people, and the category "them" - the elite, others - which is negatively valued. A majority of researchers point to such aspects of populism as creating an idealized image of the people, anti-elitism and the exclusion of out-groups, a charismatic leader (Canovan, 1999), a narrative of crisis and threat (Moffit, Tormey, 2014; Taggart, 2004), and a rhetoric employing colloquial language, emotional statements, aggressive forms in addressing political rivals, simplifications and directness (Canovan, 1999; Moffit, Tormey, 2014).

According to Kriesi (2014), as "an expression of the populist ideology, populist communication strategies may be used to identify the populist ideology empirically". Such empirical research may be conducted on the basis of both quantitative and qualitative studies employed in the social sciences, political science and media studies (Wimmer, Dominick, 2006; Croucher, Cronn-Mills, 2015; Dobek-Ostrowska, Sobera, 2017). Both types of methods have their advantages.

Quantitative studies are conducted on large samples and are about transforming observations into a set of empirically verifiable data which is statistically analyzed later on (Anderson, 2012, after: Dobek-Ostrowska, Sobera, 2017). Therefore their objectivity index is higher and they are more exact. Qualitative studies, in turn, concern a smaller number of examined cases which provide the basis for explaining and generalizing about the relations and links identified. They serve the purpose of obtaining information on the individual properties of the individuals examined, their attitudes, motivations, beliefs, ways of thinking and perceiving reality, and so on (Gibbs, 2011).

The objective of this paper is to analyze two research tools applied in the social sciences for quantitative and qualitative studies respectively, namely the codebook, or coding scheme, and individual in-depth interview - in terms of their applicability for studies of populist political communication. In particular, we address following questions: (1) What are the main benefits of using a code- 
book or an individual in-depth interview in the studies on the populist political communication? (2) What are the limits of using a codebook or an individual in-depth interview in the studies on the populist political communication? (3) What are the main challenges of using these research tools in the international comparative studies on the populist political communication?

To this end, three codebooks serving as tools for media content analysis in the above-mentioned international studies conducted in Europe in 2012-2017 are critically reviewed, and the structure of a questionnaire for in-depth interviews planned within the COST Action IS1308 Populist Political Communication in Europe: Comprehending the Challenge of Mediated Political Populism for Democratic Politics is analyzed.

Table 1. lists the international projects wholly or partly dedicated to populist political communication that provided materials for this analysis, namely: (1) The Appeal of Populist Ideas and Messages (NCCRIII - Module 2), (2) COST Action IS1308 Populist Communication in Europe: Comprehending the Challenge of Mediated Political Populism for Democratic Politics and (3) Election News in Europe: What is Covered and How?

Table 1. List of international research projects

\begin{tabular}{|l|l|l|c|}
\hline \multicolumn{1}{|c|}{ Project } & \multicolumn{1}{|c|}{$\begin{array}{c}\text { Countries where quantitative } \\
\text { studies are conducted }\end{array}$} & $\begin{array}{c}\text { Starting date of } \\
\text { studies }\end{array}$ \\
\hline 1. & $\begin{array}{l}\text { The Appeal of Populist Ideas and } \\
\text { Messages (NCCRIII - Module 2) }\end{array}$ & $\begin{array}{l}\text { Austria, Bulgaria, Switzerland, } \\
\text { Germany, Denmark, France, Italy, } \\
\text { Netherlands, Poland, Sweden, United } \\
\text { Kingdom, USA }\end{array}$ & 2014 \\
\hline 2. & $\begin{array}{l}\text { COST Action IS1308 Populist } \\
\text { Communication in Europe }\end{array}$ & $\begin{array}{l}\text { Switzerland, France, United } \\
\text { Kingdom, Bulgaria, Czech Republic, } \\
\text { Germany, Greece, Israel, Italy, } \\
\text { Norway, Poland, Serbia }\end{array}$ & 2014 \\
\hline 3. & $\begin{array}{l}\text { Election News in Europe: What is } \\
\text { Covered and How? }\end{array}$ & $\begin{array}{l}\text { Greece, Portugal, Poland, Croatia, } \\
\text { Spain, Ireland }\end{array}$ & 2015 \\
\hline
\end{tabular}

Source: own elaboration.

It should be stressed that all these research projects were initiated by scholars collaborating within the NEPOCS network (Network of European Political

1 Each author of this paper took part in at least one of these projects. 
Science Scholars). The codebooks in projects (1) and (2) were designed by the teams headed by F. Esser (University of Zurich), and in project (3) by S. Salgado (University of Lisbon). The content of the questionnaire was designed by the Working Group 1 appointed under the COST Action IS1308, headed by S. Salgado (University of Lisbon) and J. Stanyer (Loughborough University).

\section{QUANTITATIVE METHODS FOR CONTENT ANALYSIS: CODEBOOK}

Content analysis is a research method that "systematically describes, categorizes, and/or makes inferences about communication messages" (Croucher, CronnMills, 2015). Since this method serves the purpose of measuring the amount of something in a representative sampling of some mass-mediated messages, it is employed to study a wide array of theoretical questions, including those related to political communication (Croucher, Cronn-Mills, 2015). A tool this method employs is a codebook.

Codebooks are collections of categories and catalogues of principles which coders should follow. Thereby, they order and specify relevant categories and define the sequence of activities required in an analysis (Saraisky, 2012). Michalczyk adds that "the point is to ensure that different coders qualify texts into the same thematic, formal-and-genre, geographical and other categories. The categories should fulfill a handful of conditions, such as disjointness, completeness, single-aspectedness and explicitness (Michalczyk, 2009). Such elements as exemplifications, definitions and key words provide guidelines for assigning specific content to the right category, thereby becoming a factor supporting both the organizational and research dimension of the content analysis procedure.

Additionally, the presence of certain sections and their sequence in the research tool ensures its readability and clarity for other researchers, which is especially important in the field of research conducted by international teams. Describing the structure of codebooks, Yan Zhang and Barbara M. Wildemuth (2005) distinguish two parts. The first part should include a theoretical section where individual categories are explained, definitions are presented and research goals are operationalized. What is meant here is to describe the stage of "operationalization which is understood as posing a research question (problem), defining notions and forming hypotheses for a given venture. In other words, it is about defining what aspects of the content we want to study and what categories we will employ to describe them" (Michalczyk, 2009). 
Questions in the codebook should fulfill the conditions of compliance and completeness, and they have to be adapted to a specific research problem (Hordecki, Piontek, 2012). This means that "every unit of analysis should be assigned only to one sub-item in a given category (...). An appropriately designed coding scheme, which is disjunctive and exhaustive, may turn out incomprehensible for coders, that is for the people who actually code the material. It is the researcher's task then to present the coding instruction in a clearer manner in the codebook and test the tool once again" (Ścigaj, Bukowski, 2012).

These recommendations become particularly important in the case of international projects, due to the scale of such ventures in terms of the size of research teams, the complexity of samples and political, social, cultural and economic diversification. A precise codebook facilitates the international and cross-cultural unification of categories and allows parallel research to be carried out in different countries.

When analyzing populist political communication, the first challenge pertains to the selection and operationalization of categories. As mentioned above, definitions of populism provide a starting point for distinguishing the main populist categories and strategies. That is why in all the studies analyzed here, coders were expected to identify and record the following: (1) references to "the people", (2) critical references to the elite and (3) critical references to "the others" (see Table 2).

Table 2. Populist strategies

\begin{tabular}{|l|l|}
\hline \multicolumn{1}{|c|}{ Category } & \multicolumn{1}{c|}{ Populist strategy } \\
\hline \multirow{4}{*}{ The people } & Approaching the people \\
\cline { 2 - 2 } & Praising the people's virtue \\
\cline { 2 - 2 } & Praising the people's achievements \\
\cline { 2 - 2 } & Describing the people as homogeneous \\
\cline { 2 - 2 } & Demanding popular sovereignty \\
\hline \multirow{4}{*}{ The elite } & Blaming the elite \\
\cline { 2 - 2 } & Discrediting the elite \\
\cline { 2 - 2 } The people and the elite & Denying elite sovereignty \\
\hline \multirow{4}{*}{ The others } & Detaching the elite from the people \\
\hline & Excluding specific groups \\
\cline { 2 - 2 } & Discrediting specific groups \\
\cline { 2 - 2 } & Blaming specific groups \\
\hline
\end{tabular}

Source: COST Action IS1308 Populist Communication in Europe 
On account of the different forms of populism (nationalistic, left-wing, agrarian, etc.) in different countries it is necessary to specify each of the above basic categories in order to reflect populism in all countries-members of the project while maintaining a certain neutrality of the document in social, political, cultural and economic terms. The conflict between universalism and the local character of categories is one of the greatest problems of all international comparative studies.

On the one hand, universal categories are indispensable in order to conduct comparative studies, which are the primary objective and essence of international research projects. The requirement of universality, in practice, enforces avoiding local contexts, linguistic calques and referring to research problems typical of a single selected region (country) or those shared by only a few regions represented in the study. On the other hand, a tool needs to be designed to allow researchers to grasp the phenomenon under analysis (in this case - populism or using a populist style of political communication) in a given national, ethnic, social, cultural and economic reality in a specified period ${ }^{2}$.

This problem emerged in the course of studies conducted under the NCCRIII project. One of the structural elements of this study involved the attribution of a unit of measurement (text) to one or several out of a list of 16 themes typical of a populist communication style. Methodological doubts were raised by the fact that populism was linked with specific themes, the more so as the range of topics listed in the codebook did not match up to all the countries participating in the study. "Immigration" was indicated as a priority theme, which was significant in many European countries, but virtually absent from public discourse in Poland prior to 2014. At the same time, the codebook did not take into account issues present in the media discourse in Poland, such as "politics as such" (competition between political parties, political conflict, mutual relations of political actors), which was the subject of a significant proportion of texts collected for the purpose of the project. Such a construction of the research tool had an impact on the criteria of the selection of materials for the research because it resulted in rejecting a large number of texts from the database, which might have affected the research results.

2 The study by P. Przyłęcki exemplifies the adaptation of a content analysis tool. He used the method designed by the Manifesto Research Group and added populist indices (categories) present in the discourse in Poland. Cf. P. Przyłęcki (2012). Populizm w polskiej polityce. Analiza dyskursy polityki. Warszawa. 
The issue of the adequacy of codebook content to the reality being studied was also related to the fact that research material was collected in 2015, the year of presidential and parliamentary elections in Poland. The codebook had been designed by the team much earlier. This resulted in the codebook failing to account for the presence of significant actors on this "new stage", as well as the offices which some political actors no longer held. This experience revealed another challenge faced by international research teams, namely the fact that all the preparatory procedures are extremely time-consuming, which may translate into the tool becoming invalid in the context of a rapidly changing social reality.

Taking this experience into account, the principles of material selection were modified in the course of the COST Action research: the thematic criterion of immigration was maintained, while an additional independent selection criterion was added - a specific journalistic genre, such as commentary, opinion or column. Consequently, the sample encompasses the materials directly concerning immigration and all the statements made by journalists, politicians and other agents falling into the category of journalistic interpretational genres (irrespective of their theme). A superordinate criterion was also adopted: materials had to concern political parties. The period of the research was set for a non-election period in all participating countries.

Other problems related to designing a research tool may refer to metacommunication and the language used to design this tool. For the codebook to be used appropriately it has to be unitary for all team members (Zhang, Wildemuth, 2005), therefore all coders should be familiar with the language it is written in. This means, in practice, that most teams write codebooks in English, as was the case of all three projects analyzed in this paper. Yet in two of them (project 1 and 2 ), some of the examples illustrating specific categories were in German.

This generates a handful of threats. First, different levels of the member teams' language competence may become a problem. Under these circumstances, the teams may resolve to translate the codebook, although this was not required in any of the projects analyzed (some teams resorted to translations, others trained their coders and coded the results on the basis of the English original). The advantage of translation is that all the descriptive definitions are formulated in the respective native languages, but errors may emerge resulting from imprecise translations or from different contexts and cultural aspects which are transmitted through language.

One way to handle these challenges is to develop an explanatory section of the codebooks and present the theoretical foundations of the study to be 
conducted. This seems to be justified both in substantive and practical terms - at any time, every team member has the opportunity to refer to the basic concepts and definitions and refer the case under analysis to the general principles of the research. An exceptionally useful part of the codebooks features examples that help identify the categories sought and resolve disputed issues. It is therefore necessary for the examples to match all the assumptions of the definition section, while being explicit enough to make the coding process easier, not more difficult. The same applies to the language used: it is advisable to provide examples in coders' native languages, enabling them to make a direct reference to the material coded.

The level of detail of the individual tools used is determined by the Codebook Depth Index (CDI) calculated by multiplying the number of pages in the codebook and the number of categories coded (including sub-categories that require a separate code unit). Table 3 presents the statistics of the three codebooks under analysis.

Table 3. Volume of codebooks analyzed and their level of detail

\begin{tabular}{|l|c|c|c|}
\hline \multicolumn{1}{|c|}{ Project } & Page count & $\begin{array}{c}\text { Number of catego- } \\
\text { ries analyzed }\end{array}$ & $\begin{array}{c}\text { Codebook Depth } \\
\text { Index }\end{array}$ \\
\hline $\begin{array}{l}\text { The Appeal of Populist Ideas and } \\
\text { Messages (NCCRIII - Module 2) }\end{array}$ & 199 & 61 & 3.26 \\
\hline $\begin{array}{l}\text { COST Action IS1308 Populist Commu- } \\
\text { nication in Europe }\end{array}$ & 60 & 67 & 0.89 \\
\hline $\begin{array}{l}\text { Election News in Europe: What is } \\
\text { Covered and How? }\end{array}$ & 23 & 47 & 0.49 \\
\hline
\end{tabular}

Source: own elaboration.

This data reveals crucial differences between the numbers. While the number of categories analyzed is relatively similar (deviating by under ten units from the arithmetical mean of 52.25), the number of standard pages is much more varied (amounting to nearly 120 units) which has a significant impact on the CDI. The most elaborate codebook was designed for the NCCRIII project (61 categories described on nearly 200 pages) and the simplest one for Election News in Europe (47 categories on 23 pages). There is a tendency then to shorten and simplify that part of the codebooks dedicated to the theoretical introduction and category presentation. This generates a number of significant consequences for the data coding process. 
In terms of methodology, the level of detail when describing individual categories and the precision of their conceptualization should translate into such elements of the research process as the course and results of coders' reliability tests and the repeatability of results. In the field of media content analysis, these issues should be even more specified, since we often deal (as is the case of social sciences in general) with vague categories which have to be conceptualized in an exhaustive and explicit manner.

Nevertheless, the practice of coding processes demonstrates the necessity of the reasonable development of tools to such a level of detail as will not subsequently trigger a series of undesirable factors at the level of data coding, such as (1) extended duration of the process of tool preparation, (2) the necessity of running numerous and lengthy training sessions, which generates considerable expenses in international research circles, (3) extended average time of text unit coding, where coders are required to repeatedly refer to long and complicated codebooks and (4) the increasing possibility that, as the volume of text grows, so does the lack of precision and potential for error, for instance at the stage of translating the tool into a universal language or into respective national languages.

This leads us to the challenges of the coders' work. The fact that they represent different cultures has an impact on their communication styles and mode of work, thereby potentially influencing the decisions project participants make when coding individual categories. It should be borne in mind that individuals coming from the same culture differ from one another in terms of emotional sensitivity, among other things. Therefore, such elements as precise definitions of categories, training sessions in using codebooks and reliability tests are even more important in an international project. Let us emphasize that in each project analyzed in this paper great importance was attached to these aspects. All coders were trained for several days at least; in the case of the NCCRIII project, the coders spent nearly a week at a training session in Zurich, whereas two three-day training sessions were organized (in Zurich and Paris) under the COST Action. Coder reliability was calculated both for individual national teams and for all coders under the project. For the calculation of reliability in the COST Action, we relied mostly on Fretwurst's lotus (see: Fretwurst, 2015a), which is especially suited for comparative research. The unstandardized lotus can be directly interpreted and represents the percentage agreement of coders with the category most used by all coders. The standardized lotus is a chance-corrected version that also takes the number of categories used by coders into account. The advantage of this is that we can directly compare all coders for each category. 


\section{QUALITATIVE METHODS: INDIVIDUAL IN-DEPTH INTERVIEW}

Individual in-depth interview (IDI) approached as a complement of quantitative methods is part of the endeavor of reliable cognition and understanding, which "calls for the combination of different procedures and studies of socio-political phenomena through methods that may be burdened by different kinds of limitations and errors which, however, are mutually compensated for" (Krauz-Mozer, 2009). IDI may be applied as an exploratory method preceding a concrete research procedure, or as a basic, or exclusive method applied. It is interpretational in nature, falling into the tradition of hermeneutic cognition (Sztompka, 2007) which aims not to explain social phenomena, but to describe and interpret them, thereby facilitating better understanding of these phenomena and social processes alike (Krauz-Mozer, 2005).

Individual in-depth interviews are used in order to examine subjective opinions typical of the representatives of different social groups characterized by a distinct and compact group identity (Flick, 2006). IDI takes the form of a direct conversation with a single respondent. The objective of IDI is to obtain information about the current state of affairs from a given respondent, selected on the basis of criteria determined by the researcher. A significant advantage of this method is that it allows the direct influence of other people on the content and range of answers obtained to be excluded, thereby significantly facilitating collecting frank, extensive and thoughtful responses.

Interestingly, IDI has not hitherto been extensively applied in studies on political processes. Thus it should be strongly emphasized that this tool was resorted to in the above-mentioned project conducted under the COST Action IS1308 Populist Communication in Europe: Comprehending the Challenge of Mediated Political Populism for Democratic Politics. The objective of the partly structured individual in-depth interviews carried out under this project was to examine how populism is perceived in different countries, how its recent popularity is explained and whether it is perceived as positive or negative for democracy. The initial assumption was that populism and populist political actors are generally perceived as negative by both politicians and the media. The latter frequently present populism and populist politicians as a threat to democracy and pluralism. Populism in the political discourse in Europe and the United States is understood in different manners, therefore, another research objective was to identify these differences in the context of similar phenomena, such as racism, nationalism, civil involvement, as well as the left- or right-wing 
provenance of these phenomena. It was also of interest to the researchers to analyze what assumptions, associations and prejudices are most common, and whether there are any observable models of populism in Europe.

From the point of view of researchers of populist political communication, IDI has distinct advantages: it makes it possible to examine the way respondents think and perceive the world, and their motivations, value systems, attitudes, assessments and so on. The results obtained in the interviews provide a starting point for finding out and comprehending the activities of actors who exert the greatest impact on the form of contemporary political communication and on the political process this communication is a part of. Exploratory research intending to seek better cognizance of participants' motivation and activities, seems to be of particular merit and cognitive value in this field of academic investigation (Szymańska, 2017). The primary research procedure of IDI is open questions, which should not contain any elements whatsoever that might suggest the directions of possible answers. The point is to create a situation where respondents spontaneously respond to the research topic, sharing their subjective knowledge and assessment. It is worth emphasizing that IDI is an excellent tool for examining individuals whose professional status and achievements predispose them to take the role of experts and public opinion leaders (Nicpoń, Marzęcki, 2010).

In the above-mentioned project the group of future respondents encompasses politicians and journalists. The assumption is that they have a well-established position in their circles. The most desirable politicians are party leaders, influential political advisors, elected politicians, representatives of different groups: left-wing, right-wing, centrist as well as populist - defined in conformity with the criteria provided by a recently published study that reviews contemporary European populism studies (Aalberg et al., 2017). Another group of respondents is professional journalists who report on political events and enjoy a well-established position, representatives of different media (the press, television, radio, Internet websites), preferably of a national range, different profiles (left-wing, right-wing, centrist) and featuring varied journalistic types (quality and tabloid journalism). It was assumed that a group of at least eight respondents (four politicians and four journalists) from every country participating in the project will suffice the purpose of a comparative study.

The first difficulty that is typical of qualitative studies emerges at the stage of selecting potential respondents. In order to fulfill the objective of the study it is necessary for the respondents selected to agree to take part in the study, and to take into account a number of organizational and temporal limitations. 
Earlier experience shows that politicians and journalists differ in terms of their openness to studies and honesty in their contacts with researchers (Krasowski, 2015). It is therefore essential to reach out to desirable respondents, create an appropriate climate by means of clearly specifying the research goal and ensure absolute anonymity to the respondents. Researchers must take into account the agenda of their respondents and frequent collisions of their commitments with the research procedure timeline. For this reason, conversations via Internet communicators and telephones are admissible, although preference is given to direct interviews. In the case of telephone interviews, however, the opportunity to examine nonverbal reactions and the physical setting of the interaction, which is significant for its course, is limited.

In order to facilitate comparative studies, all interviews should be conducted on the basis of a standardized questionnaire with a limited number of open questions that do not suggest or lead to any answers. Giving the respondents complete freedom in responding to questions may adversely influence the achievement of research objectives, therefore additional questions are permitted in order to explain potential ambiguities. Yet it is important for the interviewees to feel that they are not pressed in any manner or that a concrete answer is expected of them. Such interventions are only admissible when the respondents do not address the question in their unstructured responses. Questions should not be constructed so as to test the respondents' knowledge, or appear to do so, because the research objective is not to assess the theoretical knowledge the respondents possess; additionally, the impression that they are being tested may adversely influence the respondents' willingness to be interviewed.

In order to find out how politicians and journalists from different countries define populism and how they perceive its influence on democracy, a list of five open questions was designed. Question one is about the general understanding of what populism is. Answers collected here should help determine what the respondents identify as populism and what examples of parties, politicians and activities defined as populist they indicate. It will be interesting to see whether they use precise definitions or rather intuitive reasoning, and whether they perceive populism as a positive or negative phenomenon; and finally, whether in their opinion the style of populism we are dealing with depends on the political actor using it and the context.

In question two, the respondents are asked to assess the consequences of populism for the countries where they are professionally active and for the condition of democracy in general. On the basis of the answers collected, the 
researchers want to determine what types of influence the respondents indicate and whether there are any differences across Europe in terms of the frequency of positive or negative outcomes of populism.

In the next question, the respondents will be asked to present their opinion on the reasons for the popularity of populist leaders and parties. It will be interesting to find out whether the respondents point to international factors (the situation in Europe, functioning of European institutions, particular events, such as the economic crisis, migration crisis and so on) or rather to internal factors (domestic politics, security, culture, political culture, the media, personalities of individual politicians).

The purpose of the fourth open question will be to determine the social issues that are perceived as most associated with populism in a given country. Listening to the answers, the interviewers should take notes of the issues mentioned, individual policies and - when in doubt - they should ask the respondents to specify their answers, especially when they fail to indicate particular examples.

Question five will address the media and their role in populist political communication. The respondents will be asked to express their opinion on whether the media covering political issues favor populism in their respective countries (and, if so - to what extent), or whether they are critical of populism. They will be also requested to indicate which media take a populist course in their opinion. The objective of this question is to determine whether the respondents believe that populism is a broader social phenomenon which may involve the media. It will be interesting to find out what the general assessment of media relations in the context of populism is: do the respondents believe that the media report the activities of political entities deemed to be populist, or that they refuse to cover such agents in their materials, which is an expression of the medium's conscious and purposeful editorial policy which opposes populism.

For the analysis to be exhaustive and effective, it will be necessary to transcribe the interviews in full. In order to compare the results, all interviews or their essential parts will have to be translated into English and the available software ensuring high recording quality and thematic coding will have to be used. The transcripts should indicate contextual variables, such as the physical setting where the interview is carried out, distractors and nonverbal behavior which is significant for the interpretation of verbal utterances. The success of the study will depend equally on the data collected and its interpretation. The objective of the project under analysis is a cohesive analysis of material collected in different countries. It may be effective to use thematic analysis which 
"is a method for identifying, analysing and reporting patterns (themes) within data" (Braun and Clarke, 2006). Both the advantages and shortcomings of this method have been exhaustively discussed (cf. e.g. Aronson, 1995; Braun, Clarke, 2006), but it is considered a useful and efficient method of the analysis of data collected via IDI.

Quantitative methods employed in social research have certain drawbacks which may be augmented in international research. One such drawback is the above-mentioned readiness of selected respondents, in particular renowned politicians and journalists, to take part in the study. Alongside their individual personalities, of key importance is the type of political culture of a given country, the respondents' awareness of the significance of academic research, as well as their freedom in specific political systems. Another factor concerns the relatively subjective nature of the interpretation of the results obtained. The researchers come from different academic circles where different research paradigms may prevail. The problem of adequate translation from respective national languages to the language of the project (English) is equally important, and this should also account for semantic nuances. Defining research as qualitative means concentrating on the properties of objects, processes and meanings that are not experimentally verifiable or quantifiable in terms of their number, size and frequency. Emphasis is given to the socially constructed nature of reality, and attention is given to the situational constraints affecting the research (Denzin, Lincoln, 2011). Such situational constraints can be highly diverse, not only inside a given country but also individually, and by nature they are not subjected to operationalization.

\section{CONCLUSIONS}

Studies on populist political communication are focused on the participants of communication processes (political actors, the media and citizens) and the messages they form and disseminate. Content analysis and individual in-depth interviews help find out the views and assessments as well as relations between different participants in communication processes. Nevertheless, each method entails a number of challenges, especially in the case of international studies. This analysis makes it possible to conclude that problems may emerge at every stage of research procedure, starting with defining categories, through the selection 
of material for analysis, to organizing team work and the process of coding the content of research material.

Having collected information about three international research initiatives coordinated by the same persons, it has been possible to grasp the evolution of research procedures and tools. The experience gathered in the course of the NCCRIII project, and the influence exerted by participants in the subsequent projects, has resulted in an expansion of the criteria for material selection and the precise determination of the time of research - either during an election period (in the case of the Election News in Europe project), or non-election period (in the case of the COST Action IS1308) in all the countries participating in the respective projects. This was accompanied by codebooks getting shorter and simpler. All the projects assigned the same considerable significance to the proper training of coders and achieving appropriate results of inter-coder reliability tests.

The evolution of research initiatives is additionally enhanced by the participating researchers, who represent different perspectives and employ different methods. That is why individual in-depth interviews are planned under the COST Action IS1308 project, alongside the content analysis of political messages disseminated by the media. By this token, it will be possible to acquire deeper knowledge about the perception of populism in different countries and the assessment of this phenomenon by politicians and journalists.

\section{ReFERENCES:}

Aalberg, T., Esser, F., Reinemann, C., Strömbäck, J., de Vreese, C.H. (eds.). (2017). Populist Political Communication in Europe. New York: Routledge.

Akkerman, A., Mudde, C., Zaslove, A. (2014). How Populist Are the People? Measuring Populist Attitudes in Voters. Comparative Political Studies, 47(9), 1324-1353.

Anderson, J.A. (2012). Media Research Methods. Understanding Metric and Interpretative Approaches. Los Angeles-Singapore: Sage.

Aronson, J. (1995). A Pragmatic View of the Thematic Analysis. The Qualitative Report, 2(1), 1-3.

Bélisle, P., Joseph, L. (2017). Codebook Cookbook. A Guide to Writing a Good Codebook for Data Analysis Projects in Medicine. Retrieved from http://www.medicine.mcgill. ca/epidemiology/joseph/pbelisle/ CodebookCookbook/CodebookCookbook.pdf.

Bieliński, J., Iwińska, K., Kordasiewicz, A. (2007). Analiza danych jakościowych przy użyciu programów komputerowych. ASK, 16, 89-114. 
Braun, V., Clarke, V. (2006). Using Thematic Analysis in Psychology. Qualitative Research in Psychology, 3(2), 77-101.

Canovan, M. (1999). Trust the People! Populism and the Two Faces of Democracy. Political Studies, 47(1), 2-16.

Croucher, S.M., Cronn-Mills, D. (2015). Understanding Communication Research Methods. A Theoretical and Practical Approach. New York: Routlegde.

Denzin, N.K., Lincoln, Y.S. (2011). Introduction: The Discipline and Practice of Qualitative Research. In: N.K. Denzin, Y.S. Lincoln (eds.), The SAGE Handbook of Qualitative Research. Fourh Edition (pp. 1-20). London: SAGE.

Dobek-Ostrowska, B., Sobera, W. (2017). Rola metod badawczych w studiach komunikologicznych. In: B. Dobek-Ostrowska, W. Sobera (eds.), Badania ilościowe i jakościowe w studiach nad komunikowaniem (pp. 19-31). Wrocław: Wydawnictwo Uniwersytetu Wrocławskiego.

Flick, U. (2006). An Introduction to Qualitative Research. London: Sage.

Franzosi, R. (2017). Content Analysis: Objective, Systematic, and Quantitative Description of Content. Retrieved from http://www.unive.it/media/allegato/ScuolaDottorale/2011/allegato/Content_Analysis_Introduction.pdf.

Freeden, M. (1996). Ideologies and Political Theory: A Conceptual Approach. Oxford: Clarendon Press.

Fretwurs, B. (2015). Lotus Manual Reliability and Accuracy with SPSS. Retrieved from http://www.iakom.ch/Lotus/LotusManualEng.pdf.

Gibbs, G. (2011). Analizowanie danych jakościowych. Warszawa: PWN.

Hordecki, B., Piontek, D. (2012). Metodologia badań nad tabloidyzacją. Atheneum. Polskie Studia Politologiczne, 36, 28-44.

Jagers, J. Walgrave, S. (2007). Populism as Political Communication Style: An Empirical Study of Political Parties' Discourse in Belgium. European Journal of Political Communication, 46(3), 319-345.

Krasowski, P. (2013). Kampania parlamentarna 2011 roku z perspektywy sztabowca. Warszawa: Wydawnictwo Wydziału Dziennikarstwa i Nauk Politycznych UW.

Krauz-Mozer, B. (2009). Metodologia politologii w perspektywie pluralistycznej. In: K.A. Wojtaszczyk, A. Mirska (eds.), Demokratyczna Polska w globalizującym się świecie (pp. 156-167). Warszawa: Wydawnictwa Akademickie i Profesjonalne.

Kriesi, H. (2014). The Populist Challenge. West European Politics, 37(2), 361-378.

Laclau, E. (2005). On Populist Reason. London: Verso.

Michalczyk, S. (2009). Uwagi o analizie zawartości mediów. Rocznik Prasoznawczy, vol. 3, 95-109.

Moffitt, B., Tormey, S. (2014). Rethinking Populism: Politics, Mediatisation and Political Style. Political Studies, 62(2), 381-397.

Mudde, C. (2004). The Populist Zeitgeist. Government and Opposition, 39(4), 541-563. Mudde, C., Rovira Kaltwasser, C. (2013). Populism. In: M. Freeden, L.T. Sargent, M. Stears (eds.), Oxford Handbook of Political Ideologies (pp. 493-512). Oxford: Oxford University Press. 
Nicpoń, M., Marzęcki, R. (2010). Pogłębiony wywiad indywidualny w badaniach politologicznych. In: D. Mikucka-Wójtowicz (ed.), Przeszłość - Teraźniejszość - Przyszłość. Problemy badawcze młodych politologów (pp. 245-252). Kraków: Libron.

Reinemann, C., Aalberg, T., Esser, F., Strömbäck, J., de Vreese, C.H. (2017). Populist Political Communication: Toward a Model of Its Causes, Forms, and Effects. In: T. Aalberg, F. Esser, C. Reinemann, J. Strömbäck, C.H. de Vreese (eds.), Populist Political Communication in Europe (pp. 12-25). New York: Routledge.

Rooduijn, M. (2014). The Nucleus of Populism: In Search of the Lowest Common Denominator. Government and Opposition, 49(4), 572-598.

Saraisky, N.G. (2015). Analyzing Public Discourse: Using Media Content Analysis to Understand the Policy Process. Current Issues in Comparative Education, 18(1), $26-41$.

Sztompka, P. (2007). Socjologia. Analiza społeczeństwa. Kraków: Wydawnictwo Znak. Szymańska, A. (2017). Europa dziennikarzy. Kraków: Wydawnictwo Uniwersytetu Jagiellońskiego.

Ścigaj, P., Bukowski, M. (2012). Zastosowanie analizy zawartości w badaniach politologicznych. Atheneum. Polskie Studia Politologiczne, 36, 11-27.

Taggart, P. (2004). Populism and Representative Politics in Contemporary Europa. Journal of Political Ideologies, 9(3), 269-288.

Wimmer, R.D., Dominick, J.R. (2006). Mass Media Research. An Introduction. Wadsworth: A Cengage Learning Company.

Zhang, Y., Wildemuth, B. (2005). Qualitative Analysis of Content. Analysis, 1(2), 1-12. 